\title{
GRAVE 1/94 AND NEW DATA REFINING THE CHRONOLOGY OF EARLY MEDIEVAL CASTLE HILL IN NITRA ${ }^{1}$
}

\author{
Z B I G N I E R O B A K ${ }^{(0)}$ - PETER B E D N ÁR (D)
}

\begin{abstract}
Based on a detailed analysis of the equipment and stratigraphy of grave 1/94 on Nitra Castle, the present paper presents most recent information about the chronology of the settlement on the Castle Hill. Burying the dead on the hill started with the early medieval settlement in the area $\left(8^{\text {th }} / 9^{\text {th }} \mathrm{c}\right.$.) and continued until the destruction of the wooden-soil chamber rampart in the second half of the $11^{\text {th }} \mathrm{c}$. Grave $1 / 94$ itself should be dated back to the second half of the $9^{\text {th }} \mathrm{c}$. The density of equipped graves in the north-east part of the hill shows that the area was used primarily for funeral purposes. Graves were found in the area of the Plague Column and in the casemates of the south-eastern bastion. Probably, the area had served as a burial ground before the wooden-soil fortifications around the castle (rampart I) were built in the second half of the $9^{\text {th }} \mathrm{c}$. Funerary customs only changed at the end of the $11^{\text {th }} \mathrm{c}$. when the area by the St. Emmeram's Church was transformed into a cemetery.
\end{abstract}

Keywords: Slovakia, Early Middle Ages, Great Moravia, burials, warrior's equipment.

\section{INTRODUCTION}

Nitra Castle not only architectonically dominates the region but also significantly contributes to our understanding of the beginnings of Slovak and Hungarian history. From the beginning of the $20^{\text {th }} \mathrm{c}$., the castle origins have been - and still are - the subject of numerous debates of archaeologists, historians and art historians (Červinka 1928; Hodál 1930; 1933; Píc 1904-1905; Škultéty 1924; Zavadil 1912). The debates allowed the formation of two main hypotheses defended by two groups of researchers. Based on unverified assumptions, the first group believes that the castle should be dated back to the first half of the $9^{\text {th }}$ c. (Hodál 1931; 1933; Stránsky/Cserenyey 1933). The second group, in turn, relies on findings of research performed between 1930 and 1931 and points that there is no evidence of the castle existence in the $9^{\text {th }} \mathrm{c}$. Instead, those researchers claim that the castle was built after Nitra was incorporated into the Kingdom of Hungary (Böhm/Mencl 1931, 65 ff.; Chropovský 1991, 159 ff.; 1997; Mencl 1933). More detailed information about the castle history, however, was provided by the research started in 1988. The results corroborate the view that castle history reaches back to the $9^{\text {th }} \mathrm{c}$. In the earliest phase, there had only been a wooden palisade strengthened later with a rampart made from wood and soil and shelled with stones. Already in the earliest phase, there was a masonry building at the top of the hill. The existence of such construction was confirmed by

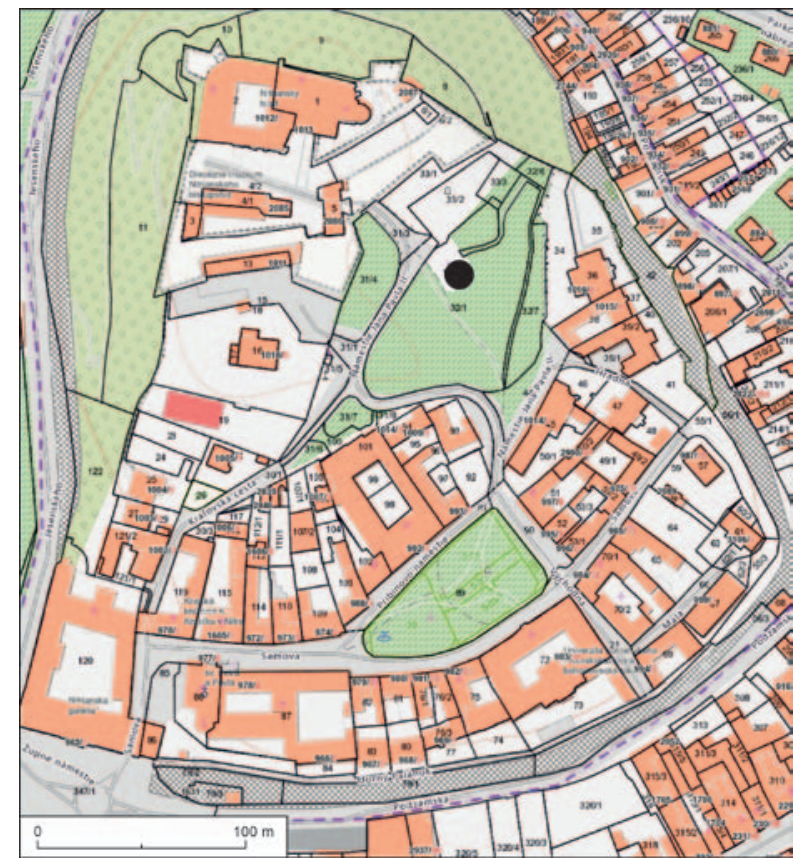

Fig. 1. Nitra-Castle. Excerpt from the cadastral map of Nitra with marking of the investigated area at the Plague Column. Source of the underlying map https://zbgis.skgeodesy.sk/ mkzbgis/sk/kataster (author P. Bednár).

\footnotetext{
1 Study produced with the support of the projects: VEGA 02/0143/18 Medieval village and its backland, VEGA 2/0124/20 Economy of the Middle Ages ( $6^{\text {th }}-13^{\text {th }}$ centuries), APVV-19-0563 Centres of the power and their backland in $8^{\text {th }}-11^{\text {th }}$ centuries and APVV-16-0449 Medieval Nitra in material sources.
} 


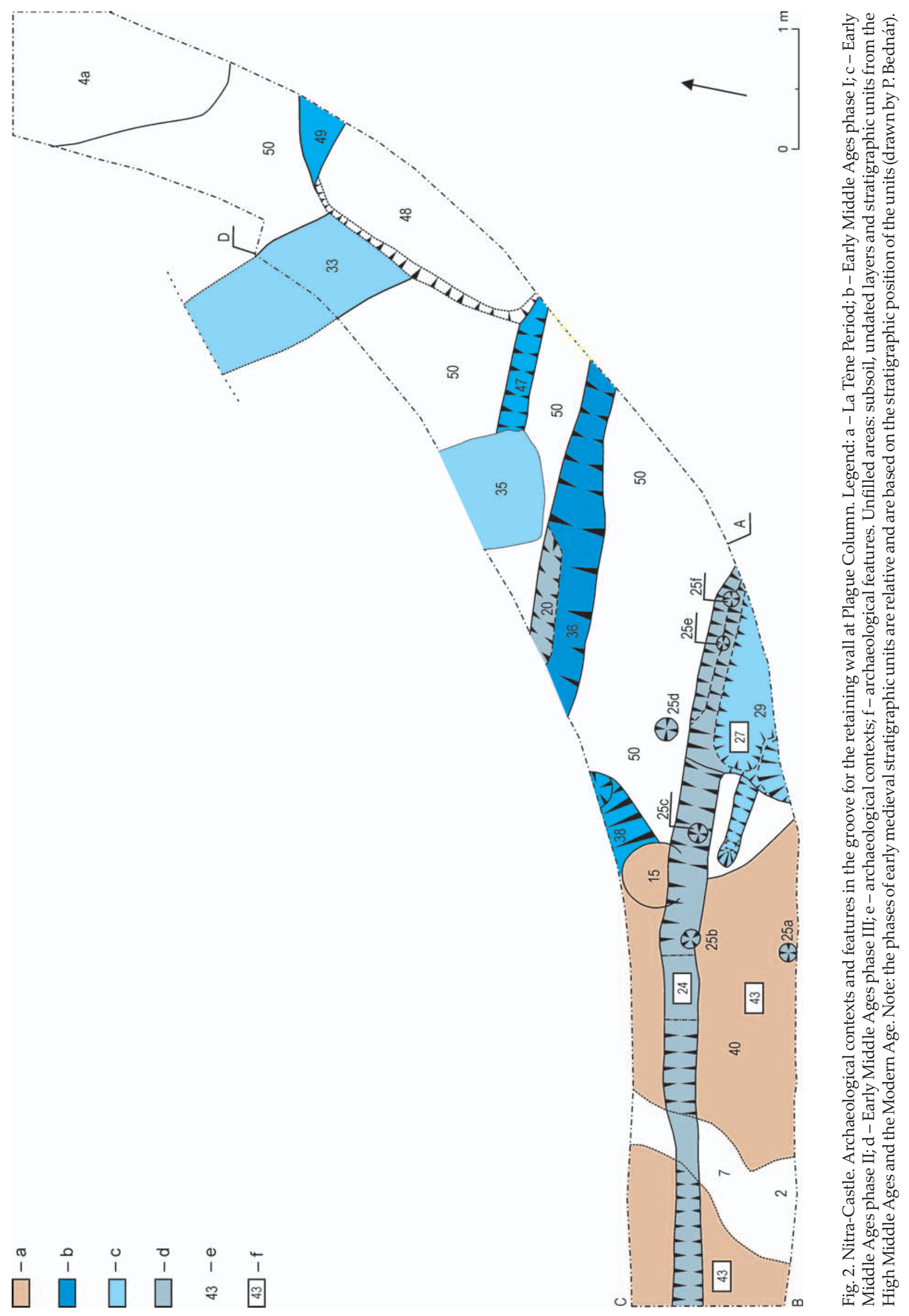



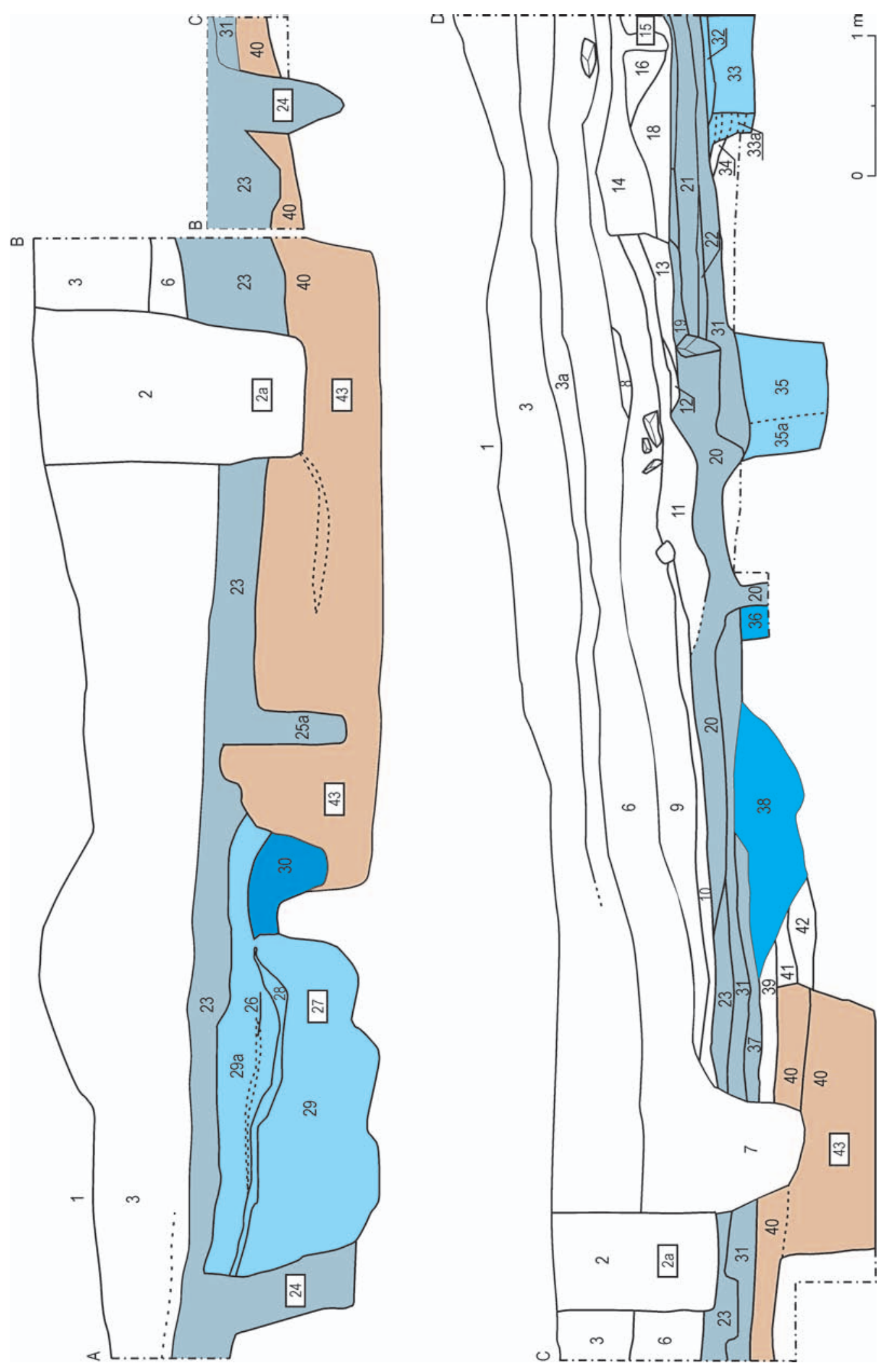

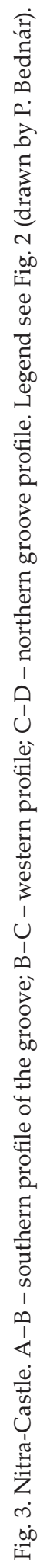




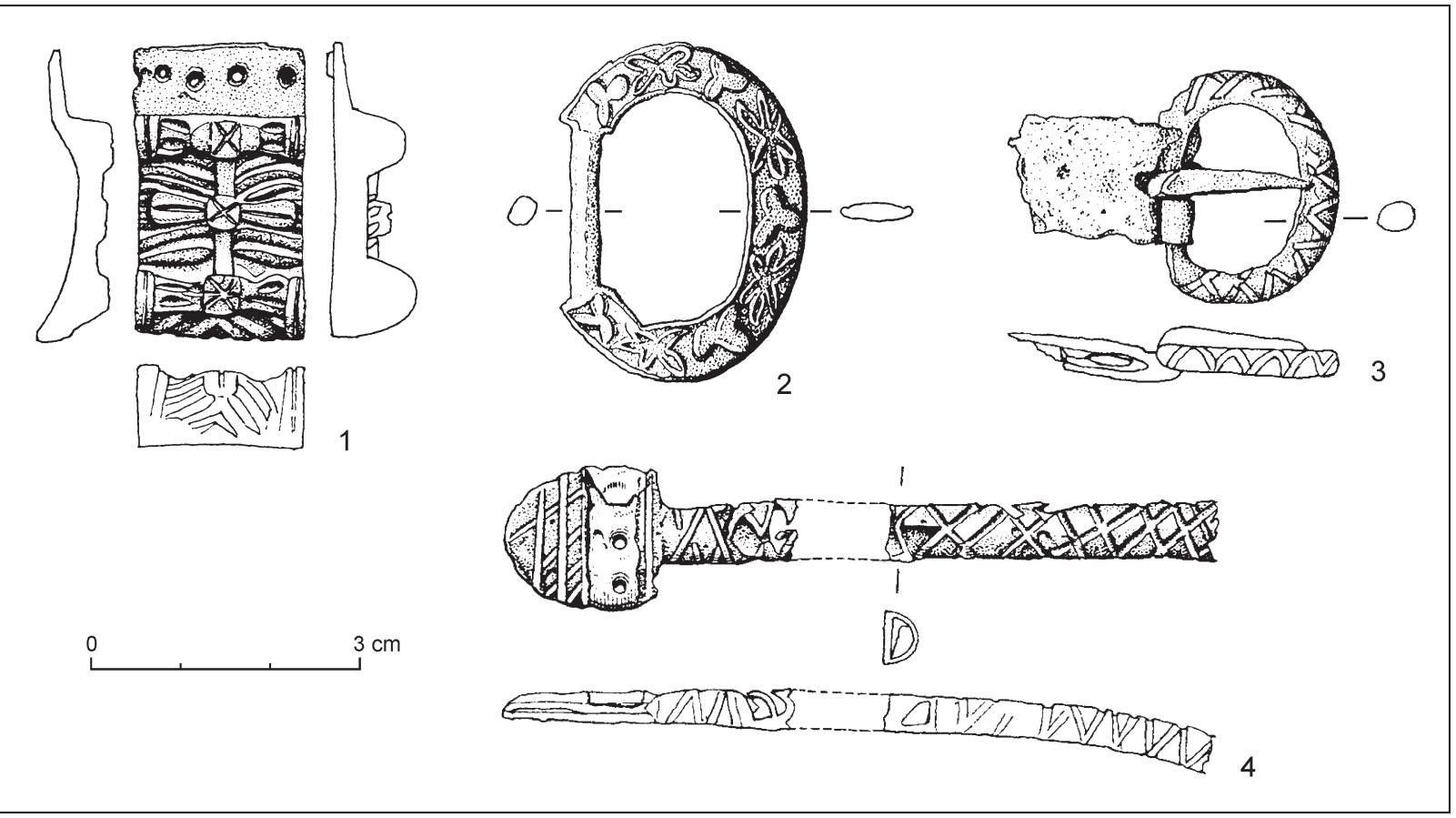

Fig. 4. Nitra-Castle. Finds from the grave 1/94 (drawn by M. Novotná).

finds of places where the mortar was mixed, mortar itself and secondarily used debris. The mere existence of a masonry construction - related to the earliest early medieval archaeological contexts indicates that the place had a unique status at the time (Bednár 1996; 1998; 2011; Bednár/Ruttkay 2018, 233; Bednár/Samuel 2001; Bednár/Staník 1993).

The castle hill served as a place for burying the dead already in the early phases of the early medieval settlement, i.e. at the turn of the $8^{\text {th }}$ and $9^{\text {th }} \mathrm{c}$. (Bednár 2001, 31; Bednár/Ruttkay 2018, 234). Unfortunately, most of the graves were unequipped and, thus, it is possible to date the graves only based on stratigraphic contexts. The only exception is a group of graves from the casemates under the SE bastion where earrings were found (Bednár 1998) - and two graves on the John Paul II Square, close to the Plague Column (Bednár 1996).

Archaeological research in this part of the hill started already between 1930 and 1931 (Točík 1983) and continued in 1958-1959 (Točík/Rejholec 1993) and 1990 (Bednár/Březinová/Fusek 1992, 23). Apart from mixed pottery in apparently younger medieval and modern-age contexts, the research, however, revealed no traces of cultural layers or features attributable to the Early Middle Ages. It was only the rescue research in 1994 preparing the ground for foundations of a new retaining wall of the Plague Column in the John Paul II Square (Fig. 1) that revealed well-stratified and dated early medieval layers and features (Bednár 1996).
The finds include one of the most interesting early medieval graves discovered on the castle hill in Nitra so far - grave no. 1/94. Although the grave is poorly preserved, the discovery together with the analysis of the find contributes to our understanding of the chronology of the early medieval settlement on the hill.

\section{STRATIGRAPHIC SITUATION}

(Fig. 2;3)

The oldest archaeological context documented in the trench (context 44, not on the profile) could be related to the Madarovce Culture. Two contexts, 41 and 42, impossible to be precisely dated, were violated by a Late La Tène sunken house (feature 43) which backfill slightly slipped over the sunken house outline. Context 34, 39 and 46 could not be dated or stratigraphically linked with other contexts.

The oldest early medieval horizon, most likely, is represented by contexts 47 and 49 . The context 47 comprises remains of a palisade ditch running along the $\mathrm{E}-\mathrm{W}$ line. The backfill contained no artefacts. Attributing the feature to the Early Middle Ages relies only on the backfill structure, similar to other early medieval features and the fact that it is oriented in line with features 36 and 24 - both dated back to the Early Middle Ages based on pottery finds and stratigraphy. 


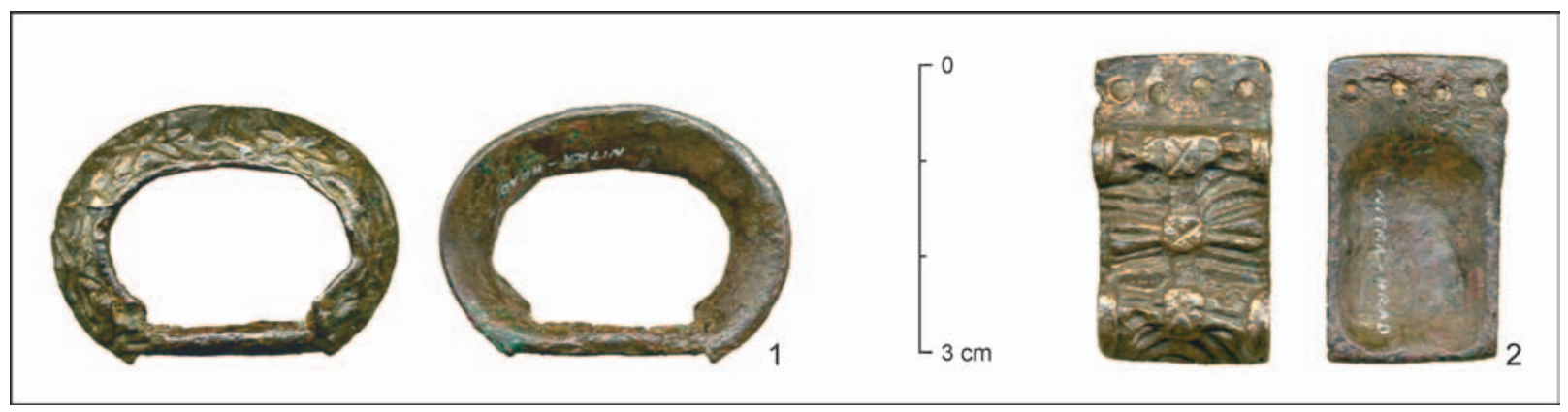

Fig. 5. Nitra-Castle. Belt set from the grave 1/94 (photo A. Arpáš).

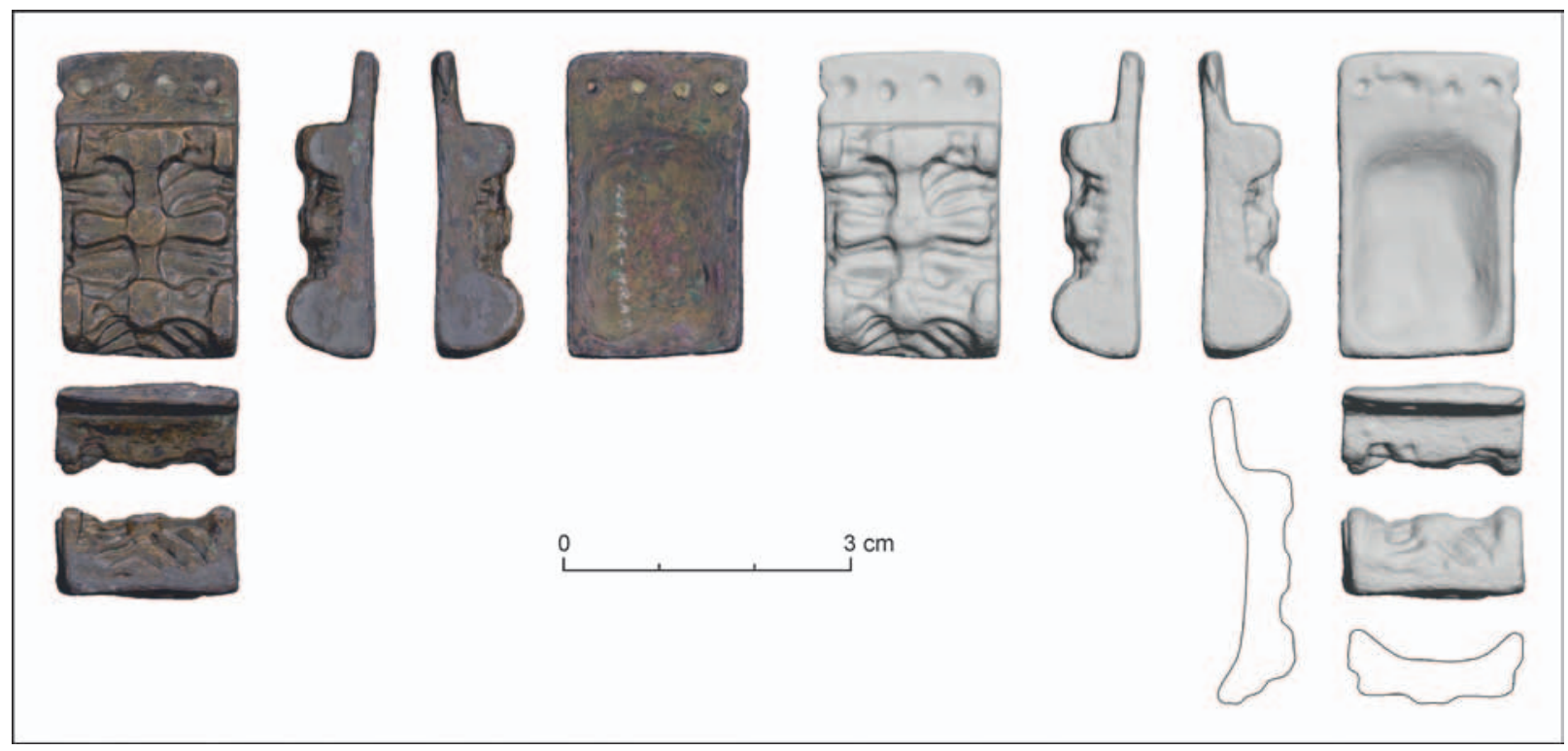

Fig. 6. Nitra-Castle. 3D image of the belt set from the grave 1/94 (photo A. Arpáš).

Grave 3/94 - labelled as context 49 - is dated back to the Early Middle Ages based solely on the backfill characteristics and its stratigraphic position. The grave was nearly destroyed by a modern-age dig no. 48. Only the skull and parts of the sternum and left forearm remained from an adult's skeleton placed on the right side along the NNE-SSW axis. Apart from the bones, the grave contained no finds.

Grave 1/94 was discovered in the vicinity of grave 3/94 and was marked as context 33 . This grave was also partially damaged by a modern-age dig no. 48. In the grave, there was an adult's skeleton. Generally, bones were arranged in anatomical order. However, both the grave and the skeleton were considerably disturbed. The grave contained a bronze buckle, a bronze strap-end and fragments of an iron spur with a buckle (Fig. 4-8). Those finds allowed to date the grave back to the Great Moravian times. Unfortunately, careless construction works damaged the grave.
Near grave 1/94, there was another grave (2/94) labelled as context 35 . The burial pit damaged a fragment of the palisade ditch no. 47. An adult was buried in the grave. The skeleton lay on the backside with arms arranged along the body. By the left side, two iron knives with remains of wooden scabbards were found.

Both graves - 1/94 and 2/94 - were aligned along the NNW-SSE axis and, thus, could be attributed to one horizon. Also, the middle palisade ditch (context 36) should be linked with those two graves. Backfills of all those features were covered with the same layer (context 31). We believe that grave 3/94 was older than 1/94. Both graves had similar depth and both were considerably damaged by modern-age digs. However, reconstruction of walls, arrangement of skeleton and dimensions of burial pits indicate that originally the graves overlapped. Unfortunately, this is exactly the spot destroyed by the modern-age dig no. 48. 


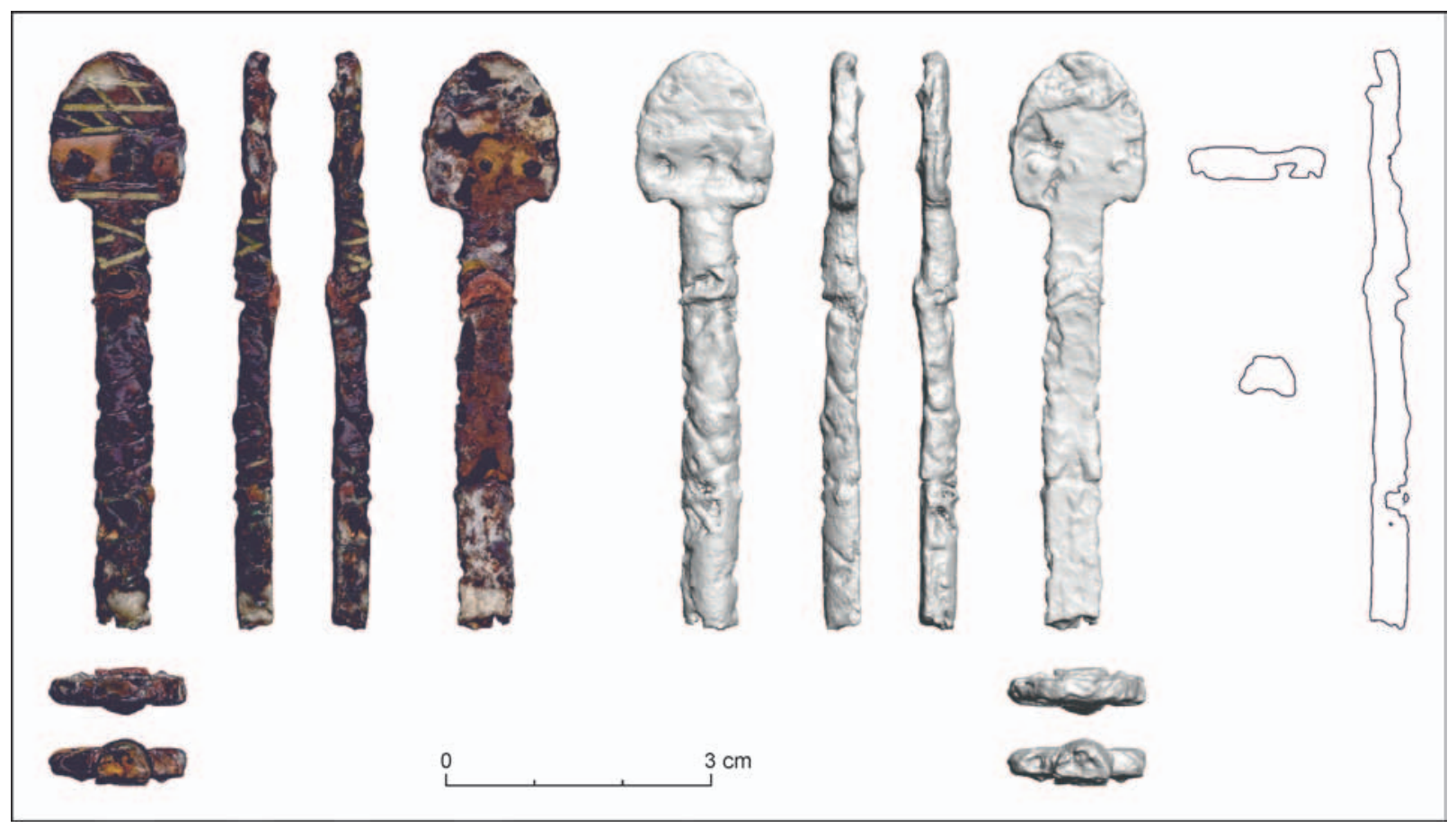

Fig. 7. Nitra-Castle. 3D image of the spur from the grave 1/94 (photo A. Arpáš).

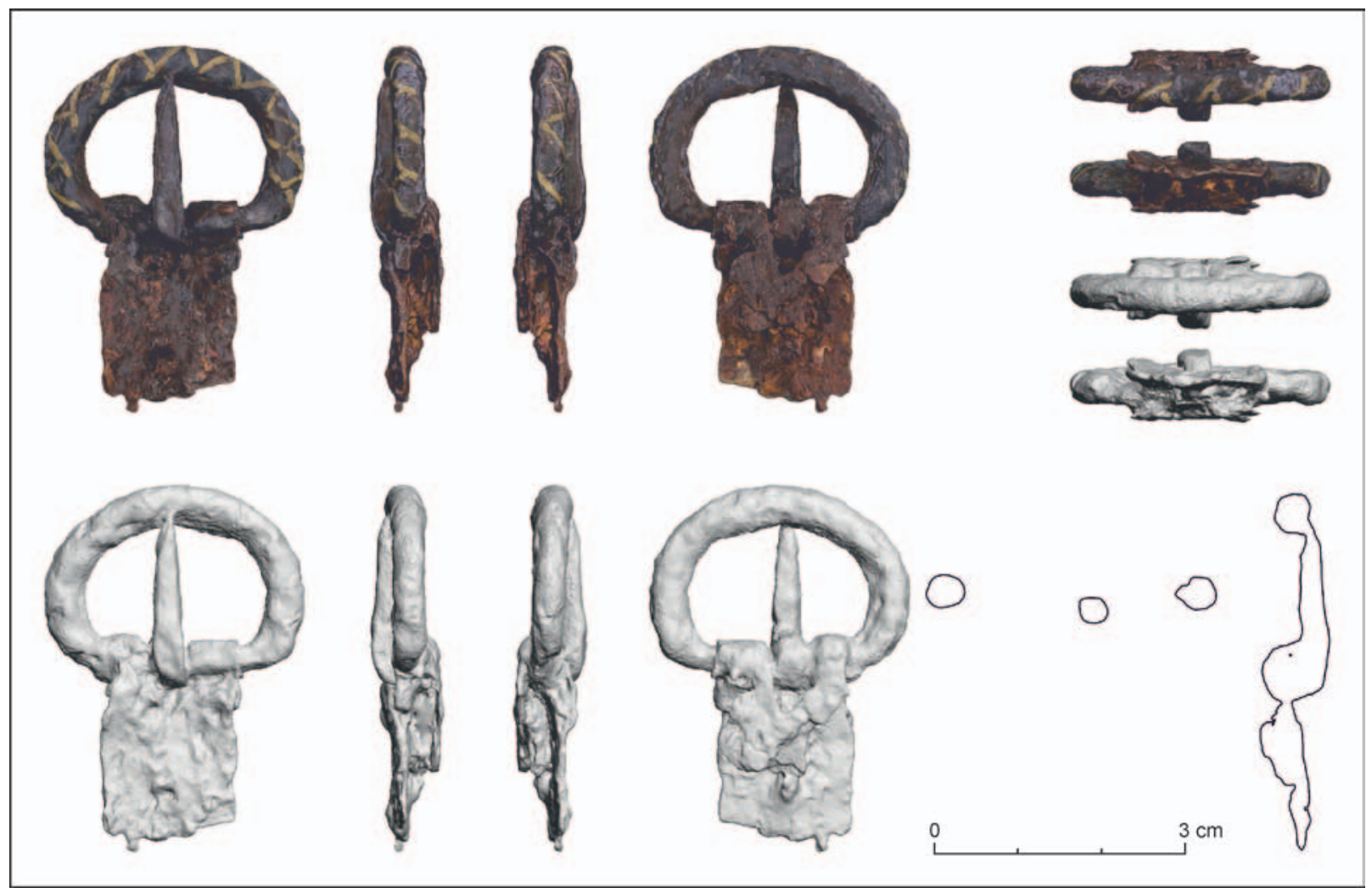

Fig. 8. Nitra-Castle. 3D image of the spur buckle from the grave 1/94 (photo A. Arpáš). 
Tab. 1. Elemental composition of the belt set from grave 1/94 from Nitra-Castle. Sampled by AI SAS Nitra.

\begin{tabular}{|c|c|c|c|c|c|c|c|c|c|}
\cline { 2 - 9 } \multicolumn{1}{c|}{} & Sample no. & $\mathrm{Cu}[\%]$ & $\mathrm{Fe}[\%]$ & $\mathrm{Zn}[\%]$ & $\mathrm{Pb}[\%]$ & $\mathrm{Sn}[\%]$ & $\mathrm{Au}[\%]$ & $\mathrm{Ag}[\%]$ & Other [\%] \\
\hline \multirow{5}{*}{ Buckle } & 230 & 75.34 & 0.44 & 0.82 & 9.19 & 12.91 & 0.15 & 0.58 & $<0.57$ \\
& 236 & 79.69 & 0.57 & 0.78 & 6.86 & 10.01 & 0.13 & 0.73 & $<1.23^{* *}$ \\
& 231 & 71.52 & $10.95^{*}$ & 0.64 & 7.98 & 8.46 & 0.12 & 0.27 & $<0.06$ \\
\hline \multirow{5}{*}{ Belt-end } & 232 & 83.64 & 2.29 & 0.59 & 8.63 & 4.66 & $<0.05$ & $<0.05$ & $<0.18$ \\
& 233 & 77.40 & 2.08 & 1.15 & 8.40 & 10.01 & 0.25 & 0.42 & $<0.29$ \\
& 234 & 80.17 & 0.98 & 0.90 & 6.40 & 10.37 & 0.19 & 0.45 & $<0.54$ \\
& 237 & 81.93 & 1.01 & 0.82 & 5.57 & 9.43 & 0.25 & 0.55 & $<0.44$ \\
& 235 & 83.54 & 0.64 & 0.46 & 8.72 & 5.93 & 0.09 & 0.38 & $<0.24$ \\
\hline
\end{tabular}

${ }^{*}$ High content of the iron has been measured in the point, where the prong was placed.

${ }^{* *}$ Incl. $0.71 \%$ of Iridium.

The research failed to discover walls of grave $3 / 94$ inside grave $1 / 94$. Thus, it seems likely that grave 1/94 partially destroyed the SW part of grave 3/94. This hypothesis is based on observations made during the grave's excavations. However, the hypothesis cannot be fully verified due to damages inflicted by the modern-age dig and then damages caused by careless construction works before the documentation.

Graves 1/94 and 2/94 were covered by a layer (context 31) containing ceramics typical of pottery workshops identified on the nearby site of NitraLupka. Products of the workshops are characteristic finds in archaeological contexts linked with early medieval Nitra settlement agglomeration. The pottery could be roughly dated back to the second half of the $9^{\text {th }}-10^{\text {th }}$ c. (Bednár/Fottová 2003; Fottová 2019).

The youngest early medieval settlement horizon in the area of the Plague Column comprises a series of settlement features. The walls of the features partially violated the backfill of the palisade ditch (context 24). There are large pits (context 29) but also features with post-holes (contexts $25 \mathrm{a}-\mathrm{f}$ ). Pottery allows dating the features back to the $10^{\text {th }}-11^{\text {th }} \mathrm{c}$. Outlines of the features were fully covered with a layer containing pottery dated back to the beginning of the $13^{\text {th }}$ c. Based on the stratigraphic information, the palisade ditch (context 24) should be placed between the graves horizon (possibly its end) and the settlement horizon.

\section{EQUIPMENT OF GRAVE 1/94}

Set of fittings decorating the main belt included a rectangular strap-end and a D-shaped buckle without a prong has been found in the grave 1/94 (Fig. 4: 1, 2; 5). The fitting was cast in a form using an alloy containing copper, tin and lead (ca. $8: 1: 1$; see Tab. 1). Consequently, the backside of the fitting is concave. A convex relief covers the entire surface of the fitting and its lower edge. The fitting was fastened to a strap with four, slightly irregularly arranged, rivets.

Most strap fittings set from Great Moravian sites could be attributed to Carolingian-type finds - i.e. fittings used in the Carolingian Empire in the $9^{\text {th }}$ and at the beginning of the $10^{\text {th }} \mathrm{c}$. The analysis shows that the stylistics of Great Moravian fittings is consistent with their Western European counterparts. Many Great Moravian finds are simply imports or direct copies or imitations of Carolingian products. Even if some groups of finds show local features, they still follow general European (Carolingian) trends in terms of forms and decorations. Consequently, it is possible to analyse Great Moravian fittings in the context of an extensive collection of Carolingian-type finds from all over Europe. This, in turn, makes the dating of such finds a considerably easier task. Particularly, since equipped Carolingian burials are scarce in Western Europe (Robak 2013; 2014).

Rectangular (or similar) strap-ends belong to a specific class of Carolingian-type fittings (class C: Robak 2013, 69-76, pl. C; CI; CV). In the entire Carolingian period (ca. 750-950), it seems, rectangular fittings were slightly less popular than U-shaped fittings. Most likely, the latter was more convenient. The rectangular shape is more common among strap decorations (applications, dividers), large slides or large fittings of main belts (including sword sets) rather than among small spur fittings.

The collection of rectangular Carolingian-type strap fittings could be divided into several stylistic groups including fittings with cylindrically bolded shorter edges of the plate or its decorated part. The best-known examples of such fittings include sword 

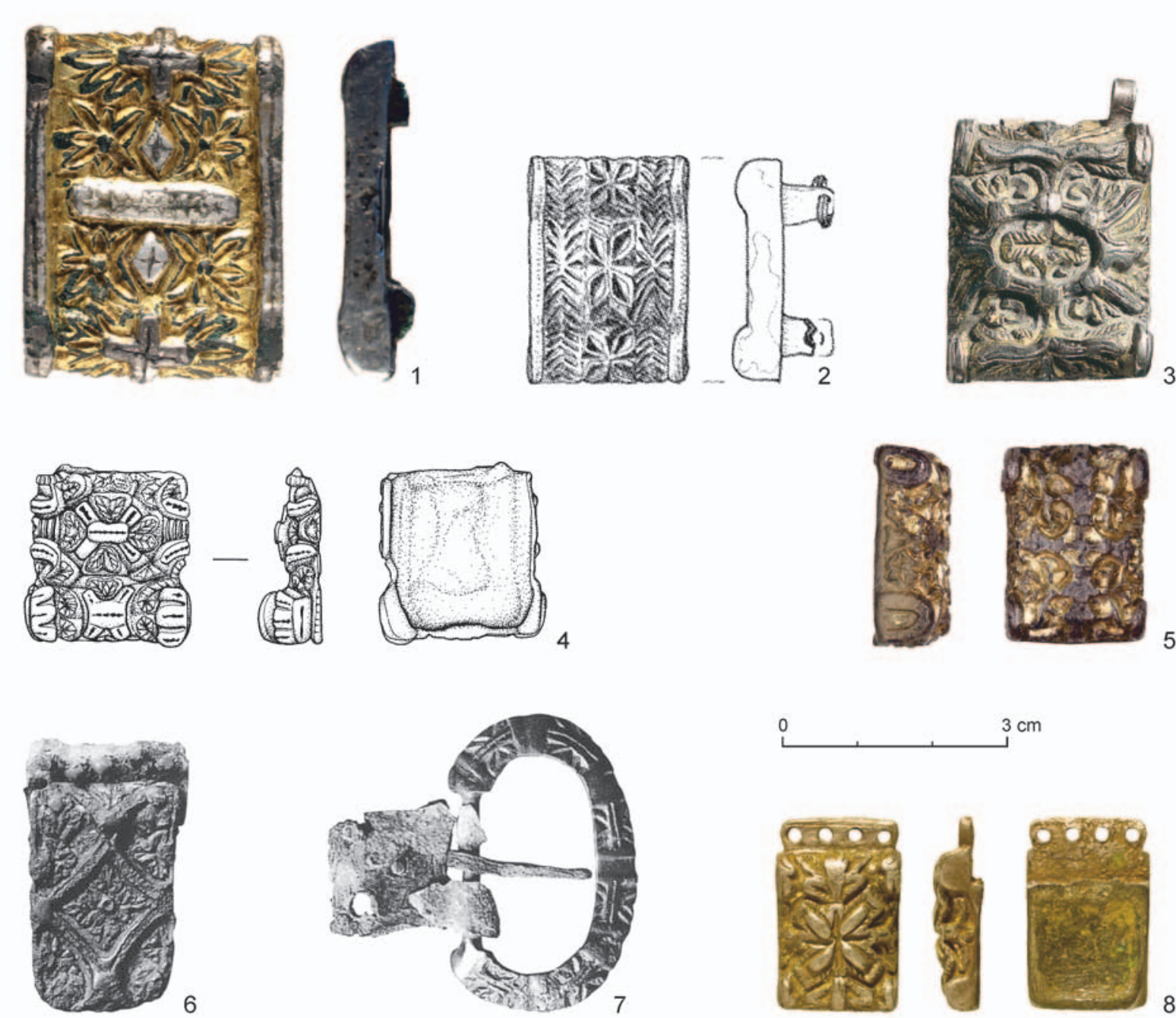

$3 \mathrm{~cm}$
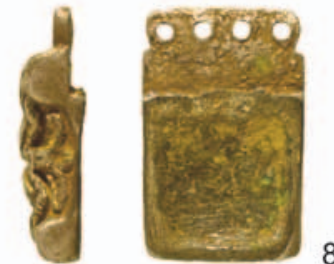

Fig. 9. Carolingian rectangular belt mounts. 1 - Hanmer, UK (after Birmingham Museums Trust, PAS: HESH-26E9D1); 2 - Ljubična nad Zbelovsko Goro, Slovenia (after Knific 2007); 3 - Duesminde, Denmark (after Wamers/Brandt 2005); 4 - Lindsey, UK (Suffolk County Council Archaeology Service, PAS: SF-E2FFD6); 5 - Hoath, UK (Kent County Council, PAS: KENT-A87012); 6, 7 - Birka, gr. 750, Sweden (after Arbman 1937); 8 - Aynho, UK (The Portable Antiquities Scheme, PAS: NARC-10F5B2. The British Museum database Portable Antiquities Scheme available at: www.finds.org.uk. The Portable Antiquities Scheme/The Trustees of the British Museum). Author Z. Robak.

sets from Marsum and Loon, lavishly decorated with plant and plant-animal ornaments (Robak 2014, pl. LXXXXVI; Ungerman 2017, 269-274), sets of horse harness fittings from Gradišče nad Bašljem (Knific 2007, fig. 2: 1-3) and fittings from baron Révay's collection known also as the Blatnica collection (Robak 2017, fig. 4: 1-9).

This group could be divided into several further variations (Robak 2017, fig. 21). The most numerous are fittings decorated with a complex plant ornament covering the entire front part of the fittings along with the edges - without a separated ornamentation field. The fitting found in grave 1/94 in Nitra represents exactly this variation. Similar strap-fittings come from Hanmer (Fig. 9: 1), Aynho
(Fig. 9: 8) and a hoard from Duesminde (Fig. 9: 3). Additionally, similar slides were found in Lindsey (Fig. 9: 4) and Hoat (Fig. 9:5) and there is also a strap fitting from Ljubična (Fig. 9: 2). However, the quality of all those finds is considerably higher.

A characteristic feature of this variation of Carolingian rectangular fittings is also the casting technique used for manufacturing the fitting from Nitra. A consequence of using the technique is a concave, rough backside masked by edges (Fig. 6). This allowed to 'spare' some of the material that could be used to form an embossed, often very sophisticated, ornament.

The fitting is decorated with a motif that could be described as a schematic, slightly simplified 
plant motif. The motif resembles a bunch tied with a tape but could be interpreted also a glowing Greek cross - which, most likely, was a manufacturer's original intention. Three additional small ' $x$ ' symbols were arranged along the axis of symmetry. Symmetrical plant ornament arranged around a centrally placed cross motif - along with additional ' + ' or ' $x$ ' symbols (Fig. 9: 1,5) - is one of the primary features of the late Carolingian style (Robak 2019). Thus, classifying the ornament as typical for late Carolingian art does not raise any doubts. Similar motifs can be seen on a U-shaped belt fitting found in grave 50/VI in Mikulčice (Fig. 10: 4, 5). The grave from Mikulčice - dug not earlier than the mid$9^{\text {th }}$ c., most likely in its second half (Galuška/Poláček 2006, 135; Košta 2008, 288; Profantová/Kavánová 2003, 61) - provides a very good chronological frame from the grave from Nitra.

Rectangular strap-ends had become popular in Western Europe about the mid-9 ${ }^{\text {th }}$ c. and in the second half of the $9^{\text {th }}$ c. - particularly in the last third - rectangular strap-ends were as popular as U-shaped forms (Robak 2013, 69-76). At the same time, this new fashion reached Central Europe. In the second half of the $9^{\text {th }} \mathrm{c}$. and at the beginning of the $10^{\text {th }} \mathrm{c}$., rectangular forms dominated in the Carolingian and Great Moravian sword sets. Cylindrically bolded edges, on the contrary, were typical for the second half of the $9^{\text {th }} \mathrm{C}$. and gradually disappeared till the turn of the $9^{\text {th }}$ and $10^{\text {th }} \mathrm{c}$. The style could be seen not only on strap fittings but also on some plate spurs with rectangular plates and bolded tips (e.g. Bialeková 1977, fig. 8: 8-10). Consequently, based on the typology and the ornament, the fitting from Nitra could be dated back to the period between the mid- $9^{\text {th }} \mathrm{c}$. and the end of the $9^{\text {th }} \mathrm{c}$.

Apart from the fitting, grave 1/94 contained also a D-shaped buckle without a prong (Fig. 4: 2; 5: 1). An iron prong did not preserve but its remains rust smudges on the frame - had been visible before the item was renovated. Traces of iron were detected also by the spectrometer (Tab. 1: sample 231). The buckle was made of the same copper alloy as the fitting and its frame was decorated with plant motifs schematic three- and six-petal flowers or leaves. Similar cast and decorated buckles - D-shaped or more oval with oblique frame - are characteristic mainly for late Carolingian items, dated back from the second third of the $9^{\text {th }}$ c. (Robak 2013, 88, 89; 2017, fig. 28). D-shaped buckles, of course, were known also in Early Carolingian times but differed in shapes and ornaments from their younger counterparts. When the Carolingian plant style dominated $\left(2^{\text {nd }}-3^{\text {rd }}\right.$ third of the $9^{\text {th }} c$.), D-shaped (and more oval) buckles were the basic type used in strap sets and were used also in combination with rectangular fittings (Robak 2014, pl. CIII). Buckles with an oblique frame decorated with a segmented plant ornament or cross motifs (crosses, rhomboids, four-pointed stars) were standard and are now found throughout Europe (Robak 2017, fig. 24). A most similar ornament to the one from Nitra can be found on an item from grave 750 in Birka - also accompanied by a rectangular, although slightly different, fitting (Fig. 9: 6, 7 ) - and a buckle from grave 433/II in Mikulčice (Klanica et al. 2019, fig. 79: 5a).

The fitting from Nitra - along with the buckle could be imported from the West. However, it is equally probable that it was manufactured in a local, Great Moravian workshop making the decoration for the local nobility in line with the general European fashion. Possibly also copying western products they saw. After all, the production of items meeting the aesthetic Western European criteria did not exceed the technological capacities of Great Moravian workshops. Also, it cannot be excluded that local noblemen 'imported' craftsmen from abroad (Brather 2001, 300). As a consequence, we are often unable to distinguish imports from items manufactured in local workshops (see Robak 2016; Ungerman 2020).

Tab. 2. Elemental composition of the spur set decoration from grave $1 / 94$ from Nitra-Castle. Sampled by AISAS Nitra.

\begin{tabular}{|l|c|c|c|c|c|c|}
\cline { 2 - 7 } \multicolumn{1}{c|}{} & $\begin{array}{c}\text { Sample } \\
\text { no. }\end{array}$ & $\begin{array}{c}\mathrm{Cu} \\
{[\%]}\end{array}$ & $\begin{array}{c}\mathrm{Fe}^{*} \\
{[\%]}\end{array}$ & $\begin{array}{c}\mathrm{Zn} \\
{[\%]}\end{array}$ & $\begin{array}{c}\mathrm{Pb} \\
{[\%]}\end{array}$ & $\begin{array}{c}\text { Other } \\
{[\%]}\end{array}$ \\
\hline Plate decoration & 226 & 61.78 & 26.02 & 11.07 & 1.03 & $<0.1$ \\
Rivet washer & 225 & 91.7 & 6.22 & 1.22 & 0.67 & $<0.19$ \\
Buckle decoration & 227 & 41.19 & 48.79 & 9.39 & 0.5 & $<0.15$ \\
\hline
\end{tabular}

* High content of the iron is caused by the fact that the spectrometer measuring area is larger than diameter of the sampled wire.

Apart from the belt set, grave 1/94 contained two fragments of an iron plate-rivet spur and an iron buckle used to fasten the spur (Fig. 7; 8). A preserved fragment of a yoke and the plate are decorated with diagonal cuts arranged into an irregular, deformed mesh. Originally, the cuts were filled with an inlaid brass wire (see Tab. 2). The upper surface of the buckle frame was decorated with a similar inlaid ornament. There, however, the cuts do not cross and the ornament resembles rather an irregular zigzag.

The spur from Nitra represents plate-rivet spurs with three rows of rivets on a small, U-shaped plate. It was one of the most popular - probably the most popular - type of spurs used in the Great Moravian times. Usually, such spurs were fastened with D-shaped or slightly oval buckles - other 


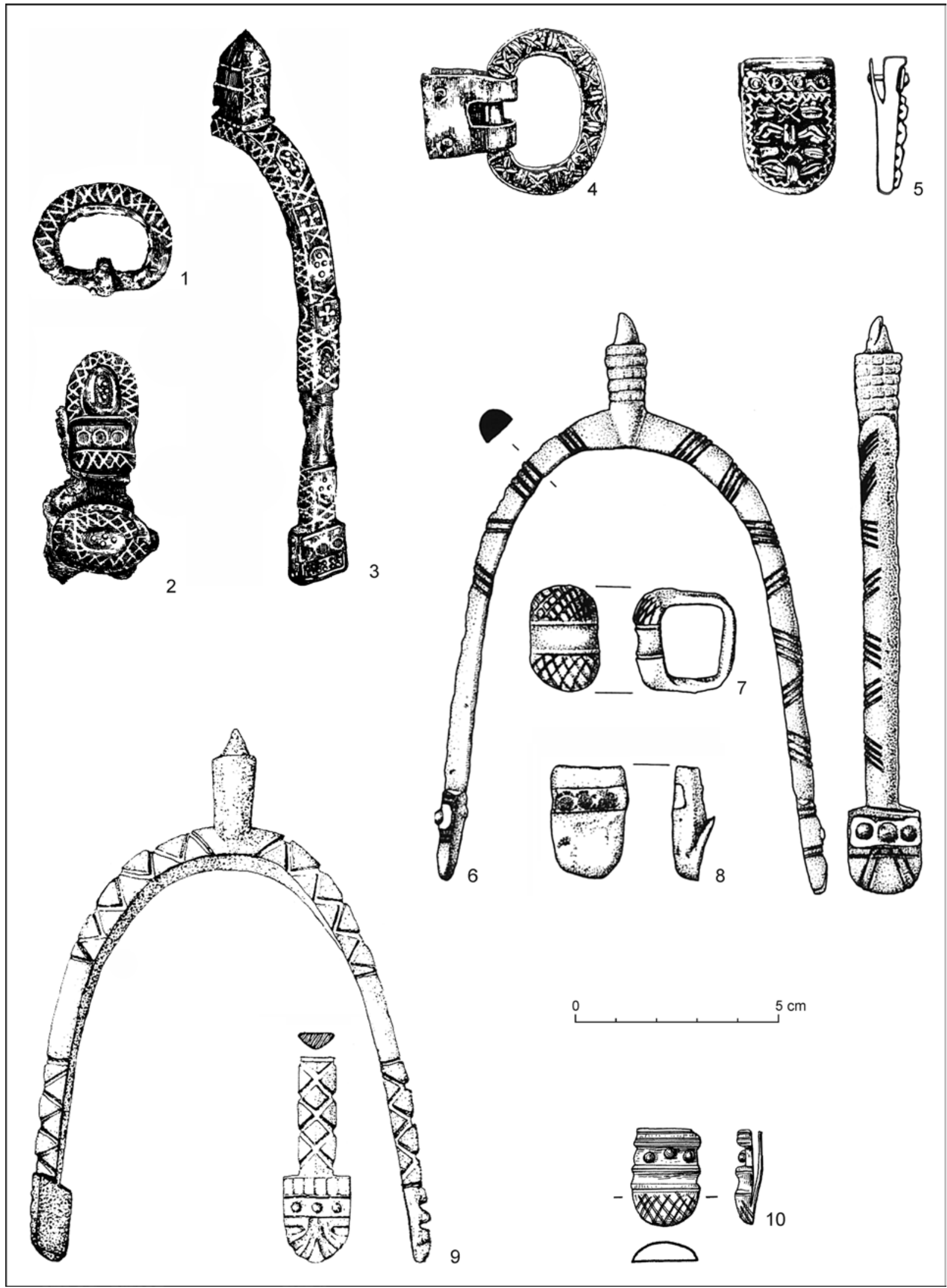

Fig. 10. Carolingian-type items with cross and mesh decoration. 1-3-Mikulčice, gr. 232/II (after Poulík 1957); 4-5-Mikulčice, gr. 50/VI (after Profantová/Kavánová 2003); 6-8 - Zalavár-Vársziget, unknown grave (after Szőke 2020); 9. Břeclav-Pohansko, gr. 277 (after Kalousek 1971); 10 - Bojná-Valy (after Robak 2014). Author Z. Robak. 
shapes are virtually absent (Robak 2013, 87-89). Plate spurs became widely used in Europe around the mid-9 $9^{\text {th }}$ c. (Košta 2008, 287; Kouřil 2020, 263; Robak 2013, 34, 35) and dominated throughout the late Carolingian Period ${ }^{2}$ and later also in the Carolingian-Ottonian and Ottonian periods $\left(10^{\text {th }}-\right.$ beginning of the $11^{\text {th }} \mathrm{c}$.) in the Carolingian Empire and neighbouring lands. Of course, with time, fasteners, number of rivets, pricks lengths and yokes evolved (see Macháček/Dresler/Přichystalová 2018, fig. 113). The small, U-shaped plate with three rivets together with a copper washer indicates that the fitting from Nitra is an item characteristic for the second half of the $9^{\text {th }}$ c. $^{3}$ Most similar spurs come from Moravia and Western Slovakia. In this region, this is a consequence of specific burial rites requiring warriors' graves to be equipped with weapons and attire - in Western Europe, this custom disappeared gradually in the $9^{\text {th }} \mathrm{c}$. - and a large number of well-studied cemeteries. Additional pieces of information are provided by iron hoards that often-included spurs. As a result, such spurs belong to the most characteristic elements of the Great Moravian material culture. However, are neither found only in Great Moravia nor were invented there. Such spurs were used throughout European regions under the Carolingian influence - they are known from German, Slovenian and Italian sites, although usually as loose finds (Robak 2013, 34).

Inlayed decorations on the spur and buckle were made of a brass wire (Tab. 2). Generally, these types of decorations were made of silver, copper or brass (Heinrich-Tamáska 2005, 135; Riederer 1994). ${ }^{4}$ In Central Europe, decorating of spurs (but also buckles, slides and spur strap fittings) with a motif of a rhomboid mesh was not rare in the Carolingian Period (see Kind 2007, fig. 2: 5). ${ }^{5}$ Although the origins of the motif are older and reach back to the Merovingian Period (Gußmann 1994, 148, pl. 22: 3d) when inlaid decorations were most popular in Europe (Menghin 1994a). Under the influence of the Merovingian and Byzantine cultures, inlaid decorations were also widely used by the Avars mainly in the Early Avar Period but also later, although less often (Heinrich-Tamáska 2005, 22-30, 135-137). Inlaid decorations were, thus, widely-available for the Great Moravian craftsmen (Bialeková 1981, 72; Galuška 1998; Kouřil 2020; Robak 2013, 136). Also, the access to western (and eastern) patterns was easy as confirmed by numerous finds of inlaid items on Great Moravian strongholds (e.g. Klanica et. al. 2019, fig. 79: 10; Kouřil 2014, Cat. no. 109; 114; 166; 170; 171; 173; 198; Robak 2014, pl. LIV: 4; XLVI: 8; XLVII: 3; XLVIII: 8; XLIX: 9). Plate spurs decorated similarly as the one from Nitra are known from graves in Mikulčice (Fig. 10: 1-3; gr. 232/II; Kouřil 2020, fig. 164) ${ }^{6}$ and Břeclav-Pohansko (Fig. 10: 9; gr. 277; Kalousek 1971, fig. 277) and some loose finds (Pobedim: Bialeková 1977, fig. 8: 8). The mesh motif can be found also on a slide from Zalavár (Fig. 10: 7; Szóke 2020, fig. 106: 6) and a spur fitting from Bojná-Valy (Fig. 10: 10; Robak 2014, pl. XLIX: 9), and also as an additional decoration of belt-ends (Robak 2014, pl. XLIX: 13; L: 1).

The upper part of the yoke and the prick did not preserve. Consequently, a more detailed typological analysis - that could provide more detailed information about the find - is impossible. The spurs decoration itself is not very helpful. However, we should notice that similar items come nearly always from central parts of Great Moravia or nearby Zalavár which in the second half of the $9^{\text {th }} \mathrm{c}$. was a seat of the Carolingian Duchy of Pannonia (Fig. 10: 6; Szôke 2020). The decorations are consistent with the general fashion of using geometric ornaments seen on Great Moravian finds dated back to the second half of the $9^{\text {th }} \mathrm{c}$. and the beginning of the $10^{\text {th }}$ c. (Robak 2013, 171-179, 190). The similarity of the decorative pattern to the spurs from graves 232/II in Mikulčice and 277 in Břeclav-Pohansko is striking (Fig. 10:1-3, 9). It seems possible, thus, that the spur and the buckle were manufactured somewhere in Great Moravia. The lack of Western European analogies is caused by the lack of material suitable for comparison. Generally, in Western Europe, there are very few spurs dated back to the $2^{\text {nd }}$ and $3^{\text {rd }}$ third of the $9^{\text {th }} \mathrm{c}$. and decorated examples are unique.

Considering the finds in the context of Carolingian-type artefacts from all over Europe, we see that the grave from Nitra was equipped with elegant middle-class products. The finds were not the most common iron spurs and fittings - used by low-rank

\footnotetext{
2 In Slovakia and Moravia, the late Carolingian Period is roughly consistent with the Great Moravian Period.

3 Originally, most likely, a prick was short or medium (max. ca. $40 \mathrm{~mm}$ ). Usually, plate spurs with long prick and U-shaped plates had only two rivets.

4 This was substantiated by more recent analyses of 'gold' inlaid strap and spur fittings from Bojná that turned out to be brass.

5 In supreme versions, the pattern was made using the technique of plating with miniature copper and silver plates (see Kouřil 2014, Cat. no. 63; Robak 2014, pl. XLI: 10).

6 P. Kouřil $(2020,266)$ believes that such spurs are, most likely, one of the early variations of Carolingian plate-rivet spurs with a transverse row of rivets. The spurs, thus, could be western products used as models for the production of local copies in Moravia.
} 
warriors - but also, they were not high-quality Carolingian or Great Moravian products. The finds are consistent with the general picture of Great Moravian finds in Slovakia, where - apart from the grave in Ducové - there are no truly noble burials and elite elements of attire that would resemble those from Staré Město and Mikulčice. Of course, this does not mean that such elite items were never present in Slovakia. However, unlike Staré Město, Břeclav or Mikulčice, Great Moravian centres in Slovakia (including Nitra and Bratislava) had not disappeared. Instead, they underwent architectonic transformations, were refurbished into stone and later also brick castles and their representative functions were maintained to this day (similarly to castles in Prague and Cracow). 1,200 years of continuous settlement and construction activities, thus, must have left traces in archaeological material. Destruction of grave 1/94 from Nitra provides yet another confirmation of this process. There are only a couple of Great Moravian graves found on the Nitra Castle but, certainly, around the bishop's church, there must have been many more of them (Bednár/Ruttkay 2018, 234).

The chronology of items found in grave 1/94 is relatively coherent and generally limited to the second half of the $9^{\text {th }} \mathrm{c}$. The two sets are consistent and, thus, there is little risk that one of the items could be archaic. Depending on how long the items were used, thus, we could assume that the artefacts were deposited in the grave between the mid- $9^{\text {th }} \mathrm{c}$. and the end of the $9^{\text {th }} \mathrm{c}$.

\section{SUMMARY}

The stratigraphic situation around the Plague Column together with comparative research to the east of the Column corroborate the view that the north-eastern part of the Nitra Castle - on the site of the present Castellum café - was intensely exploited in the Early Middle Ages (Bednár et al. 2019, 22). The density of equipped graves on a relatively small area indicates that those were not random graves - as in many other Castle areas (Bednár 2001, 31, 34) - but a site used primarily as a burial ground. The cemetery could be linked with the existence of a hillfort fortified with the rampart I built in the second half of the $9^{\text {th }}$ c. (Bednár/Ruttkay 2018, 231). There are no other settlement features contemporary to the graves or distinct early medieval settlement layers there. Settlement features (apart from prehistoric) started to appear thereafter the site had ceased to be used as a burial ground and the entire area had been reorganised (removal of internal palisades). Most likely in the $10^{\text {th }}$ and $11^{\text {th }} \mathrm{c}$.

Dating grave 1/94 back to the second half of the $9^{\text {th }} \mathrm{c}$. provides a benchmark for other early medieval burials and some other significant features in the area. The oldest phase of the burials $\left(8^{\text {th }} / 9^{\text {th }}\right.$ - first half of the $9^{\text {th }} \mathrm{c}$.) should be linked with a group of graves found under the rampart I and, thus, older than the rampart. Possibly also grave $3 / 94$ belongs to the group. Contrary to previous assumptions (Bednár 2001, 31), grave 1/94 belongs to the next phase, related to the existence of woodensoil fortifications.

The stratigraphic situation of the site, along with the information acquired during the research, confirms the previous hypothesis that Castle Hill served as a burial ground throughout all phases of the early medieval settlement in the area. The hypothesis is additionally corroborated by graves found under the construction of the oldest rampart (I) on both eastern and western slopes of the hill, by rampart I and in the destruction of rampart III (Bednár 1998; 2001, 31). In other words, the dead were buried on Castle Hill from the beginnings of early medieval settlement $\left(8^{\text {th }} / 9^{\text {th }} c\right.$.) until the destruction of the wooden-soil chamber rampart (III) in the second half of the $11^{\text {th }} \mathrm{c}$. A radical change in burial customs took place at the end of the $11^{\text {th }} \mathrm{c}$. when the area around St. Emmeram's Church was transformed into a cemetery. Graves related to the younger phase were dug into the construction and destruction of rampart III from the end of the $11^{\text {th }} \mathrm{c}$. until the $15^{\text {th }}$ c. (Bednár 2001, 35, 36). 


\section{BIBLIOGRAPHY}

Arbman 1937 - H. Arbman: Schweden und das karolingische Reich. Studien zu den Handelsverbindungen des 9. Jahrhunderts. Stockholm 1937.

Bednár 1996 - P. Bednár: Siedma sezóna výskumu Nitrianskeho hradu. AVANS 1994, 1996, 29-31.

Bednár 1998 - P. Bednár: Die Entwicklung der Befestigung der Nitraer Burg im 9.-12. Jahrhundert. In: J. Henning/ A. T. Ruttkay (Hrsg.): Frühmittelalterlicher Burgenbau in Mittel-und Osteuropa. Tagung, Nitra vom 7. bis 10. Oktober 1996. Bonn 1998, 371-382.

Bednár 2001- P. Bednár: Sídlisková štruktúra Nitry v 9. storočí. In: L. Galuška/P. Kouřil/Z. Měřinský (eds.): Velká Morava mezi východem a západem. Sborník príspěvkủ z mezinárodní vědecké konference. Uherské Hradiště, Staré Město, 28. 9.-1. 10. 1999. Spisy Archeologického ústavu AV ČR Brno 17. Brno 2001, 20-39.

Bednár 2011 - P. Bednár: Počiatky Nitrianskeho hradu. In: V. Judák/P. Bednár/J. Medvecký (zost.): Kolíska krestianstva na Slovensku. Nitriansky hrad a Katedrála sv. Emeráma v premenách času. Nitra 2011, 114-121.

Bednár/Březinová/Fusek 1992 - P. Bednár/G. Brezinová/G. Fusek: Výskumy a prieskumy v Nitre v časti Staré mesto. AVANS 1990, 1992, 23-25.

Bednár et al. 2019 - P. Bednár/K. Daňová/Z. Poláková/ M. Ruttkay/P. Smetanová/O. Žaár: Pokračovanie výskumu Nitrianskeho hradu. AVANS 2014, 2019, 19-24.

Bednár/Fottová 2003 - P. Bednár/E. Fottová: Nitra-tržnica príspevok k poznaniu stredovekého mesta. Archaeologia historica 28, 2003, 303-315.

Bednár/Ruttkay 2018 - P. Bednár/M. Ruttkay: Nitra and the Principality of Nitra after the Fall of Great Moravia. In: P. Kouřil/R. Procházka et al.: Moravian and Silesian Strongholds of the Tenth and Eleventh Centuries in the Context of Central Europe. Spisy Archeologického ústavu AV ČR Brno 57. Brno 2018, 229-244.

Bednár/Samuel 2001 - P. Bednár/M. Samuel: Entwicklung der Befestigung der Nitraer Burg im 11. Jahrhundert. Slovenská archeológia 49, 2001, 301-345.

Bednár/Staník 1993 - P. Bednár/I. Staník: Archeologický výskum Nitrianskeho hradu v rokoch 1988-1991. In: K. Pieta (ed.): Nitra. Príspevky knajstarším dejinám mesta. Nitra 1993, 127-141.

Bialeková 1977 - D. Bialeková: Sporen von slawischen Fundplätzen in Pobedim (Typologie und Datierung). Slovenská archeológia 25, 1977, 103-160.

Bialeková 1981 - D. Bialeková: Dávne slovanské kováčstvo. Dávnoveké umenie Slovenska 11. Bratislava 1981.

Böhm/Mencl 1931 - J. Böhm/V. Mencl: Výskum na hradě nitranském 1930-1931. Památky archeologické 37, 1931, 64-79.

Červinka 1928 - I. L. Červinka: Slované na Moravěa Řiše velkomoravská. Brno 1928.

Chroporský 1991 - B. Chropovský: Nitra. In: H. Brachmann/ J. Herrmann (Hrsg.): Frühgeschichte der europäischen Stadt. Grundlagen und Voraussetzungen. Schriften zur Ur- und Frühgeschichte 44. Berlin 1991, 159-165.

Chropovský 1997 - B. Chropovský: K problematike sídla Svätopluka I. In: R. Marsina/A. Ruttkay (eds.): Svätopluk 894-1994. Nitra 1997, 71-77.

Fottová 2019 - E. Fottová: Typologicko-chronologický vývoj keramickej produkcie v 8.-12. storočí v oblasti Nitry. Dizer- tačná práca. Archeologický ústav Slovenskej akadémie vied. Nitra 2019. Unpublished.

Galuška 1998 - L. Galuška: Souprava velmože z hrobu 266/49 ze Starého Města. (K poznání neobvyklé technologie výzdoby raněstředověkých předmětů.) In: P. Kouřil/ R. Nekuda/J. Unger (eds.): Ve službách archeologie. Sborník k60. narozeninám RNDr. Vladimíra Haška, DrSc. Př́spěvky z konference Př́rodovédecké metody v archeologii, Kravsko, 5.-6. břrezna 1998. Spisy Archeologického ústavu AV ČR Brno 10. Brno 1998, 95-107.

Galuška/Poláček 2006 - L. Galuška/L. Poláček: Církevní architektura v centrální oblasti velkomoravského státu. In: P. Sommer (ed.): České země v raném středověku. Praha 2006, 92-153.

Gußmann 1994-S. Gußmann: Herstellunstechnisch-typologische Untersuchungen an tauschierten Metallarbeiten. In: Menghin 1994b, 105-158.

Heinrich-Tamáska 2005 - O. Heinrich-Tamáska: Studien zu den awarenzeitlichen Tauschierarbeiten. Monographien zu Frühgeschichte und Mittelalterarchaologie 11. Innsbruck 2005.

Hodál 1930 - J. Hodál: Kostol kniežat’a Privinu v Nitre. 830-1930. Nitra 1930.

Hodál 1933 - J. Hodál: Kostol Pribinov v Nitre v pravom svetle. Nitra 1933.

Kalousek 1971 - F. Kalousek: Břeclav-Pohansko I. Velkomoravské pohřebiště u kostela. Archeologické prameny z pohřebiště. Spisy University J. E. Purkyně v Brně. Filosofická fakulta 169. Brno 1971.

Kind 2007 - T. Kind: Westliche Einflüsse auf der östlichen Balkanhalbinsel im Spiegel der früh- und hochmittelalterlichen Reitausrüstung. In: J. Henning (ed.): Post-Roman Towns. Trade and Settlement in Europe and Byzantium. Vol. 2. Byzantium, Pliska, and the Balkans. Millennium-Studien zu Kultur und Geschichte des ersten Jahrtausends n. Chr. 5/2. Berlin - New York 2007, 543-612.

Klanica et al. 2019 - Z. Klanica/B. Kavánová/P. Kouřil/ Š. Ungerman: Mikulčice. Die Nekropole an der dreischiffigen Basilika. Studien zum Burgwall Mikulčice 12. Spisy Archeologického ústavu AV ČR Brno 58. Brno 2019.

Knific 2007 - T. Knific: Zgodnjesrednjeveški pozlačeni predmeti z Gradišča nad Bašljem (Slovenija). Prilozi Instituta za arheologiju u Zagrebu 24, 2007, 317-326.

Košta 2008 - J. Košta: Několik poznámek k chronologii pohřebiště u VI. kostela v Mikulčicích. Studia Mediaevalia Pragensia 8, 2008, 277-296.

Kouřil 2014 - P. Kouřil (ed.): Velká Morava a počátky křestanství. Brno 2014.

Kouřil 2020 - P. Kouřil: Ostentatious Spurs from Mikulčice. In: L. Poláček et al.: Great Moravian Elites from Mikulčice. Brno 2020, 255-267.

Macháček/Dresler/Přrichystalová 2018 - J. Macháček/P. Dresler/R. Přichystalová: Das Ende Großmährens - Überlegungen zur relativen und absoluten Chronologie des ostmitteleuropäischen Frühmittelalters. Praehistorische Zeitschrift 93, 2018, 307-348.

Menghin 1994a - W. Menghin: Ferro splendeo opus argento. Der Silberglanz der Merowingerzeit. In: Menghin 1994b, 9-32.

Menghin 1994b - W. Menghin (Hrsg.): Tauschierarbeiten der Merowingerzeit. Bestandskataloge. Band 2. Berlin 1994. 
Mencl 1933 - V. Mencl: Stredoveká architektúra na Nitrianskom hrade. In: J. Hofman a kol.: Nitra. Dejiny a umenie nitrianskeho zámku. Trnava 1933, 61-99.

Pić 1904-1905 - J. Píć: Stopa Svatoplukovy Nitry. Památky archeologické 21, 1904-1905, 316-320.

Poulík 1957 - J. Poulík: Výsledky výzkumu na velkomoravském hradišti „Valy“ u Mikulčic. Zpráva za rok 1954-1956. Památky archeologické 48, 1957, 241-388.

Profantová/Kavánová 2003 - N. Profantová/B. Kavánová: Mikulčice - pohřebiště u 6. a 12. kostela. Spisy Archeologického ústavu AV ČR Brno 22. Brno 2003.

Riederer 1994 - J. Riederer. Metallanalysen von Silber- und Messingeinlagen aus merowingerzeitlichen tauschierten Eisenfunden. In: Menghin 1994b, 159-162.

Robak 2013 - Z. Robak: Studia nad okuciami rzemieni w typie karolińskim. VIII-X wiek. Część I. Archaeologica Slovaca Monographiae. Studia 18. Nitra 2013.

Robak 2014 - Z. Robak: Studia nad okuciami rzemieni w typie karolińskim. VIII-X wiek. Część II. Archaeologica Slovaca Monographiae. Studia 19. Nitra 2014.

Robak 2016 - Z. Robak: A comparative analysis of three fittings decorated with the Carolingian plant style coming from Mikulčice, Bojná and Zalavár. In: T. Csécs/M. Takács (szerk.): Beatus homo qui invenit sapientiam. Ünnepi kötet Tomka Péter 75. születésnapjára. Győr 2016, 617-623.

Robak 2017 -Z. Robak: The Origins and the Collapse of the Blatnica-Mikulčice Paradigm. Slovenská archeológia 65, 2017, 99-162.

Robak 2019 - Z. Robak: The Age of Migrating Ideas. A Short Contribution on Cruciform Decorations on Great Moravian Strap Fitting in the $9^{\text {th }}$ Century. In: L. Poláček/ P. Kouřril (Hrsg.): Bewaffnung und Reiterausrüstung des

Manuscript accepted 28. 9. 2021

Translated by Magdalena Adamus

Mgr. Zbigniew Robak, PhD.

Archeologický ústav SAV

Akademická 2

SK - 94921 Nitra

zbigniew.robak@savba.sk
8. bis 10. Jahrhunderts in Mitteleuropa. Waffenform und Waffenbeigaben bei den mährischen Slawen und in den Nachbarländern. Internationale Tagungen in Mikulčice IX. Spisy Archeologického ústavu AV ČR 50. Brno 2019, 453-477.

Škultéty 1924 - J. Škultéty: Starobylá Nitra. Slovenské pohlady 40, 1924, 65-87.

Stránsky/Cserenyey 1933 - A. Stránsky/Š. Cserenyey: Dejiny biskupstva nitrianskeho. Trnava 1933.

Szőke 2020 - B. M. Szőke: Pannonien in der Karolingerzeit. Monographien des Römisch-Germanischen Zentralmuseums 145. Mainz 2020.

Točík 1983 - A. Točík: Predbežná správa o výskume hradného kopca v Nitre v roku 1930-1931. AVANS 1982, 1983, 244-247.

Točík/Rejholec 1993 - A. Točík/E. Rejholec: Zistovací výskum na hradnom kopci v rokoch 1958-1959. Študijné zvesti AÚ SAV 29, 1993, 5-46.

Ungerman 2017 -Š. Ungerman: Mečové pásy z 9.-10. století v západní a střední Evropě (typologie, chronologie, provenience a symbolika). In: K. Pieta/Z. Robak (eds.): Bojná 2. Nové výsledky výskumov včasnostredovekých hradisk. 2. rozšírené vydanie. Archaeologica Slovaca Monographiae. Fontes 22. Nitra 2017, 253-280.

Ungerman 2020 - Š. Ungerman: Carolingian Imports in Great Moravia. In: L. Poláček et al.: Great Moravian Elites from Mikulčice. Brno 2020, 51-57.

Wamers/Brandt 2005 - E. Wamers/M. Brandt (Hrsg.): Die Macht des Silbers. Karolingische Schätze im Norden. Regensburg 2005.

Zavadil 1912 -J. Zavadil: Velehrady Děvín a Nitra. Kroměříž 1912.

PhDr. Peter Bednár, CSc.

Archeologický ústav SAV

Akademická 2

SK - 94921 Nitra

nraubedn@savba.sk 